\title{
IMPROVING THE HEAT BALANCE BY USING THE EXHAUST GASES FOR A TANKER SHIP
}

\author{
Article DOI : $\underline{\text { https://doi.org/10.35219/mtd.2018.2.02 }}$ \\ Catalin FAITAR $^{1) *}$, Andra Teodora NEDELCU ${ }^{2)}$, Mihail Lucian DUMITRACHE ${ }^{1)}$ \\ 1) Maritime University of Constanta, Faculty of Naval Electromechanics, 104 Mircea cel Batran, \\ RO-900663, Constanta, Romania \\ 2) Mircea cel Batran Naval Academy, Faculty of Navigation and Naval Transport, 1 Fulgerului, \\ RO-900218, Constanta, Romania \\ * Corresponding author: catalinfaitar@yahoo.ro
}

\begin{abstract}
Exhaust gas energy recovery is more preferred than the energy contained in the cooling water. This is determined by the higher exhaust gas temperature, from $250{ }^{\circ} \mathrm{C}$ to $400{ }^{\circ} \mathrm{C}$, for two-stroke engines and from $400{ }^{\circ} \mathrm{C}$ to $500{ }^{\circ} \mathrm{C}$ for four-stroke engines. Recovery is accomplished by means of a heat exchanger, called a heat recovery boiler or directly from the exhaust gas by the entrainment of a power turbine that drives an electric generator. Mitsubishi engines waste recovery systems consist of high-quality, highly efficient machinery that significantly increases overall vessel efficiency and it is an effective way to reduce the EEDI (energy efficiency design index ). Very large crude carriers (VLCC) are among the biggest working freight vessels on the planet. With a capacity more than 250,000 dwt, these big vessels are equipped with two-stroke engines of high power.
\end{abstract}

Keywor ds: heat, recovery, engine, boiler, parameters

\section{INTRODUCTIO N}

The absolute thermal balance is used when it comes to analyze the use of thermal energy on a particular engine, while the specific heat balance, as well as the relative thermal balance, are used both for analyzing the use of thermal energy and for comparing, in terms of effective efficiency, one engine to another. The distribution of the heat flows for a particular operating regime of an engine is represented graphically in Fig. 1. This figure shows the heat balance diagram in which the heat flows are divided into components corresponding to the real situation.

The lost heat flow, $Q_{p d}$, is:

$$
Q_{p d}=Q_{i n t}-\left(Q_{u}+Q_{p r}+Q_{p g}\right)
$$

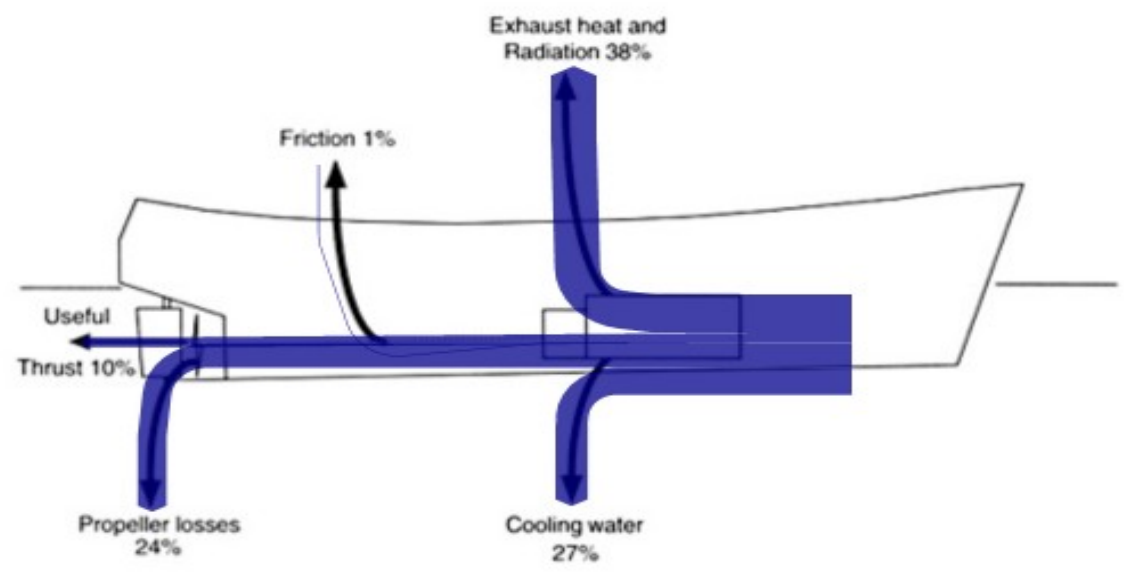

Fig. 1. Heat flow distribution [4] 
The energy flow, $Q_{p d}$, includes the following losses:

- mechanical losses that have not passed through the cooling water or in the lubricating oil,

- energy flow, equivalent to incomplete fuel combustion,

- energy flow transmitted to the environment,

- the kinetic energy of the gases - if not used,

- the energy corres ponding to calculation errors or due to experimental determinations .

\section{THE MAIN ENGINE OF A 300,000 DWT TANKER SHIP}

The propulsion of the tanker ship of $300.000 \mathrm{dwt}$ is provided by a Mitsubishi-UE MDE 7UEC85LSII, two-stroke, slow and reversible engine, with a constant overcharging pressure that develops a rated output of $27020 \mathrm{~kW}$, at a speed of $76 \mathrm{rpm}$, the ship shifting with a maximum speed of $15.38 \mathrm{Nd}$. MAN B\&W two-stroke engines from 300 to $950 \mathrm{~mm}$ bore sizes have a total power range from $1,560 \mathrm{~kW}$ to $82,440 \mathrm{~kW}$, with units that vary in height from 5,912 to $16,156 \mathrm{~mm}$. This covers the ME (400 to $950 \mathrm{~mm}$ bore), ME-GI (400 to $950 \mathrm{~mm}$ bore), ME-B (300 to $500 \mathrm{~mm}$ bore) and $\mathrm{MC}$ (350 to $700 \mathrm{~mm}$ bore) series [1], [2].

Table 1. Main engine characteristics

\begin{tabular}{cc}
\hline Characteris tics & Value \\
\hline Bore & $850 \mathrm{~mm}$ \\
Stroke & $3150 \mathrm{~mm}$ \\
Number of cylinders & 7 \\
MCR power & $27020 \mathrm{~kW}$ \\
NCR power & $22965 \mathrm{~kW}$ \\
Speed & $76 \mathrm{rpm}$ \\
\hline
\end{tabular}

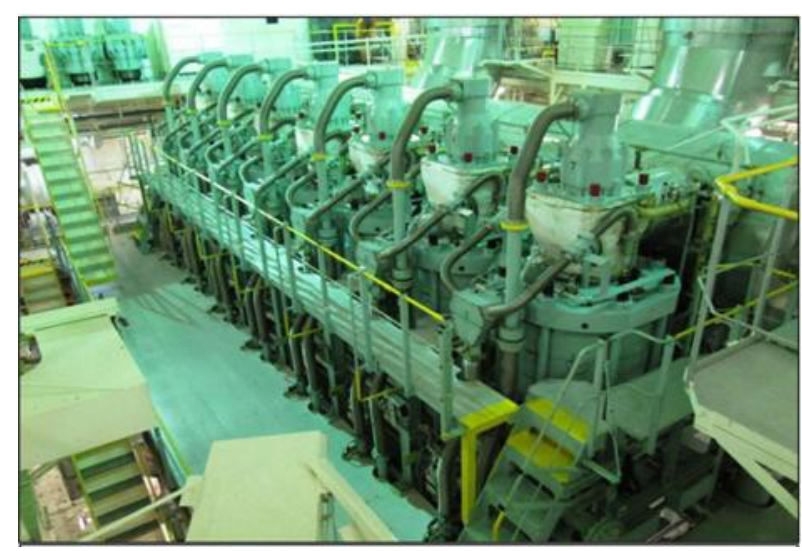

Fig. 2. Main engine type Mitsubishi-UE MDE 7UEC85LSII [5]

\section{EXHAUST GAS RECOVERY SYSTEM}

Recovery of the energy contained in the exhaust gases of the engine could be due to the relatively high temperature as compared to the cooling water temperature. This is done by means of a heat exchanger, called a heat recovery boiler, the operation of such a heat exchanger being distinguished by several characteris tics:

heat exchange in the boiler is achieved only by convection, due to the moderate exhaust gas temperature, but not less than $200 \ldots 250{ }^{\circ} \mathrm{C}$;

the gas temperature at the boiler outlet must exceed the agent temperature by $30 \ldots 40{ }^{\circ} \mathrm{C}$, in order not to unnecessarily increase the heat exchange surface;

the boiler outlet temperature should not be less than $160{ }^{\circ} \mathrm{C}$ to $170{ }^{\circ} \mathrm{C}$ in order to avoid acid dew temperature, especially when the engine is running on heavy fuel oil, with a high percentage of sulfur, to avoid corrosion of the surfaces of the channels through which flue gases circulate;

not to endanger the normal operation of the motor, the resistance of the maximum caliber gas dynamics must be less than $250 \mathrm{~mm}$ water column on the two-stroke engine and $400 \mathrm{~mm}$ water column on the four-stroke engine.

The heat flow thus recovered can be used for: production of saturated water vapor for fuel heating hard and ship needs,

production of superheated water vapor for supplying a turbo-generator for power generation.

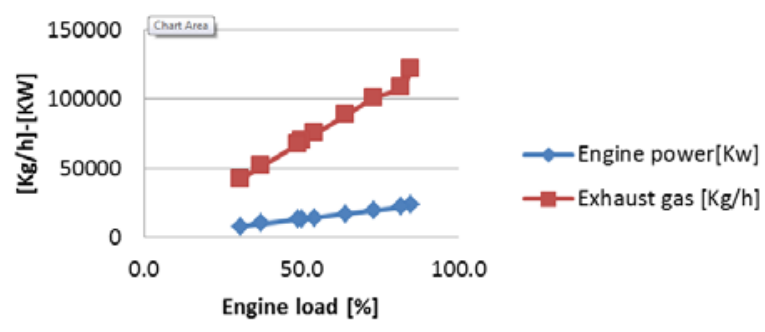

Fig. 3. Main engine power vs. exhaust gas flow

\section{ECONOMIZER SYSTEM ONBOARD SHIP}

The use of recovery heaters has an economic purpose. They are used during the march to produce steam required on board by using flue gases, discharged from the main engine (internal combustion).

On board ships are used boilers to increase the efficiency of internal combustion engines and to ensure normal working conditions for the auxiliary plants and crew. Recovery boiler has all the elements of an aquatubular boiler but for working is no longer necessary fuel combustion.

The Mitsubishi dual steam pressure exhaust gas economizer is designed by incorporating the latest heat exchanger technologies which Mits ubis hi Heavy Industries Ltd has nurtured through its long experience with the manufacture of exhaust gas economizer and main and auxiliary boiler. The dual steam pressure exhaust gas economizer has a lowpressure evaporating section, high-pressure evaporating section and superheating section, each independently arranged with inlet and outlet headers 
and also casing supports and low-pressure steam separator, which is useful to the low-pressure evaporating section.

\section{THERMAL ENERGY BALANCE}

The calculation of the heat flow at the inlet, $\mathrm{Q}_{\mathrm{gi}}$, and the the heat flow at boiler outlet, $\mathrm{Q}_{\mathrm{ge}}$ is done as following:

$$
\begin{gathered}
\mathrm{Q}_{\mathrm{gi}}=\mathrm{i}_{\mathrm{gi}} \cdot \mathrm{P} \cdot \mathrm{c}_{\mathrm{g}}=1.4 \cdot 10^{7} \quad[\mathrm{~kJ} / \mathrm{h}] \\
\mathrm{Q}_{\mathrm{ge}}=\mathrm{i}_{\mathrm{ge}} \cdot \mathrm{P} \cdot \mathrm{c}_{\mathrm{g}}=3.4 \cdot 10^{6} \quad[\mathrm{~kJ} / \mathrm{h}]
\end{gathered}
$$

where $P$ is engine power, $i_{g i}$ is inlet gas enthalpy, $c_{g}$ is specific gas heat and $i_{g e}$ is exhaust gas enthalpy.

The calculation of heat flow taken over by water on the heat path (heat available) is:

$$
\mathrm{Q}_{\mathrm{d}}=\mathrm{Q}_{\mathrm{gi}}-\mathrm{Q}_{\mathrm{ge}}=1.06 \cdot 10^{7} \quad[\mathrm{~kJ} / \mathrm{h}]
$$

The calculation of the used heat flow is:

$$
\dot{\mathrm{Q}}_{\mathrm{u}}=\eta_{\mathrm{c}} \dot{\mathrm{Q}}_{\mathrm{d}}[\mathrm{kJ} / \mathrm{h}]
$$

The calculation of steam flow, $\mathrm{D}_{\mathrm{ab}}$, is:

$$
\mathrm{D}_{\mathrm{ab}}=\frac{\mathrm{Q}_{\mathrm{u}}}{\mathrm{i}_{\mathrm{as}}-\mathrm{i}_{\mathrm{a}}}=2823 \quad[\mathrm{~kg} / \mathrm{h}]
$$

where $i_{\text {as }}$ is steam inlet enthalpy, $i_{a}$ is steam outlet enthaply

The calculation of gas flow becomes :

$$
\mathrm{D}_{\mathrm{g}}=\frac{\mathrm{Q}_{\mathrm{u}}}{\mathrm{i}_{\mathrm{gi}}-\mathrm{i}_{\mathrm{ge}}}=60923 \quad[\mathrm{~kg} / \mathrm{h}]
$$

The calculation of the average temperature difference, $\Delta \mathrm{t}_{\mathrm{m}}$, will be:

$$
\Delta \mathrm{t}_{\mathrm{m}}=\frac{\Delta \mathrm{t}_{\max }-\Delta \mathrm{t}_{\min }}{\ln \left(\frac{\Delta \mathrm{t}_{\text {max }}}{\Delta \mathrm{t}_{\text {min }}}\right)}=69.1 \quad\left[{ }^{\circ} \mathrm{C}\right]
$$

The calculation of the heat flow, $\mathrm{Q}_{\mathrm{si}}$, is:

$$
\mathrm{Q}_{\mathrm{si}}=\frac{\mathrm{D}_{\mathrm{ab}}}{\eta_{\mathrm{c}}}\left(\mathrm{i}_{\text {asie }}-\mathrm{i}_{\text {asii }}\right)=2.1 \cdot 10^{6} \quad[\mathrm{~kJ} / \mathrm{h}]
$$

where $i_{\text {asie }}$ is steam inlet enthalpy and $i_{\text {asii }}$ is steam outlet enthalpy

The calculation of the heat transfer surface, $D_{g}$, is:

$$
\mathrm{D}_{\mathrm{g}}=\frac{\mathrm{Q}_{\mathrm{si}}}{\mathrm{k} \cdot \Delta \mathrm{t}_{\mathrm{m}}}=242 \quad\left[\mathrm{~m}^{2}\right]
$$

Table 2. Gas economizer characteristics at main engine MCR (Maximum continuous rating)

\begin{tabular}{ccccc}
\hline Characteris tics & $\begin{array}{c}\text { Low-pres sure } \\
\text { evaporator }\end{array}$ & $\begin{array}{c}\text { Steam } \\
\text { separator }\end{array}$ & $\begin{array}{c}\text { High-pres sure } \\
\text { evaporator }\end{array}$ & Superheater \\
\hline Evaporating, $\mathrm{Kg} / \mathrm{h}$ & 2420 & 2420 & 5710 & 5410 \\
Designed pressure, $\mathrm{MPa}$ & 0.98 & 0.59 & 2.65 & 2.16 \\
Steam temperature ${ }^{\circ} \mathrm{C}$ & $\mathrm{Sat}$ & $\mathrm{Sat}$ & $\mathrm{Sat}$ & 245 \\
Gas flow at $85 \% \mathrm{MCR}$, & 179800 & 179800 & 179800 & 179800 \\
$\mathrm{Kg} / \mathrm{h}$ & & & 263 & 263 \\
Inlet gas temperature at & 263 & 263 & 263 \\
$85 \% \mathrm{MCR},{ }^{\circ} \mathrm{C}$ & & &
\end{tabular}

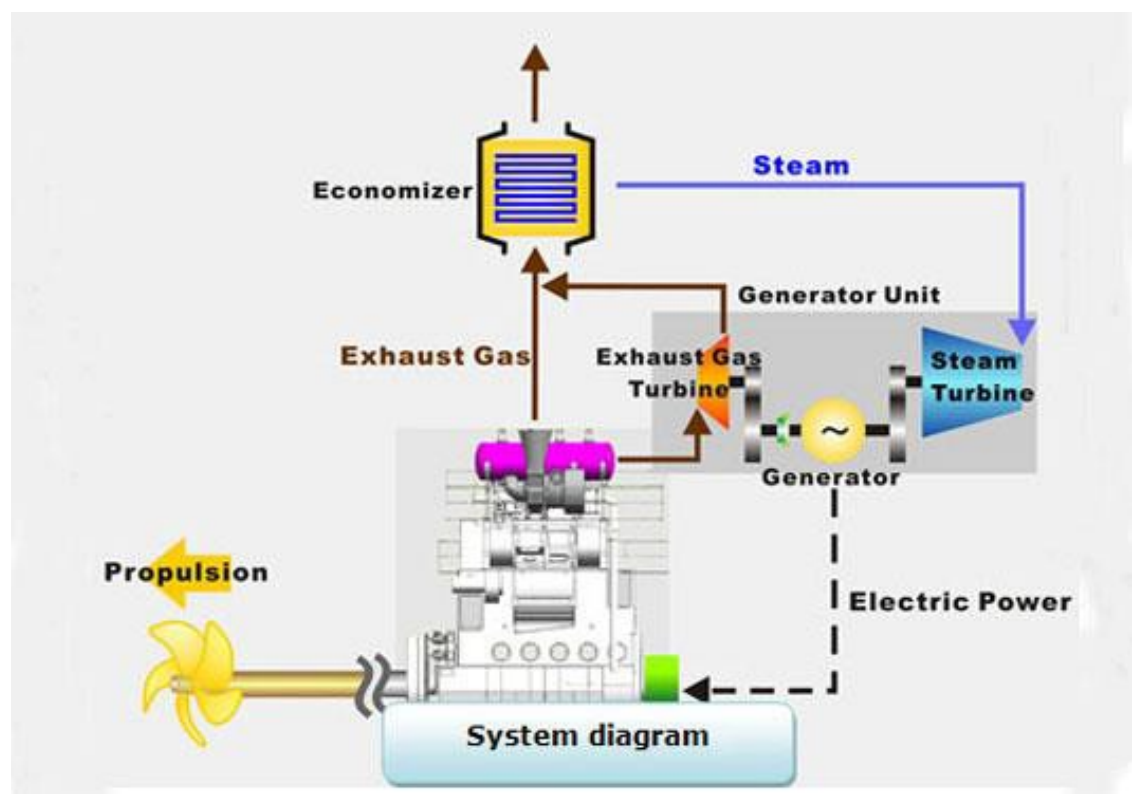

Fig. 4. VLCC (very large crude carrier) recovery system [6] 


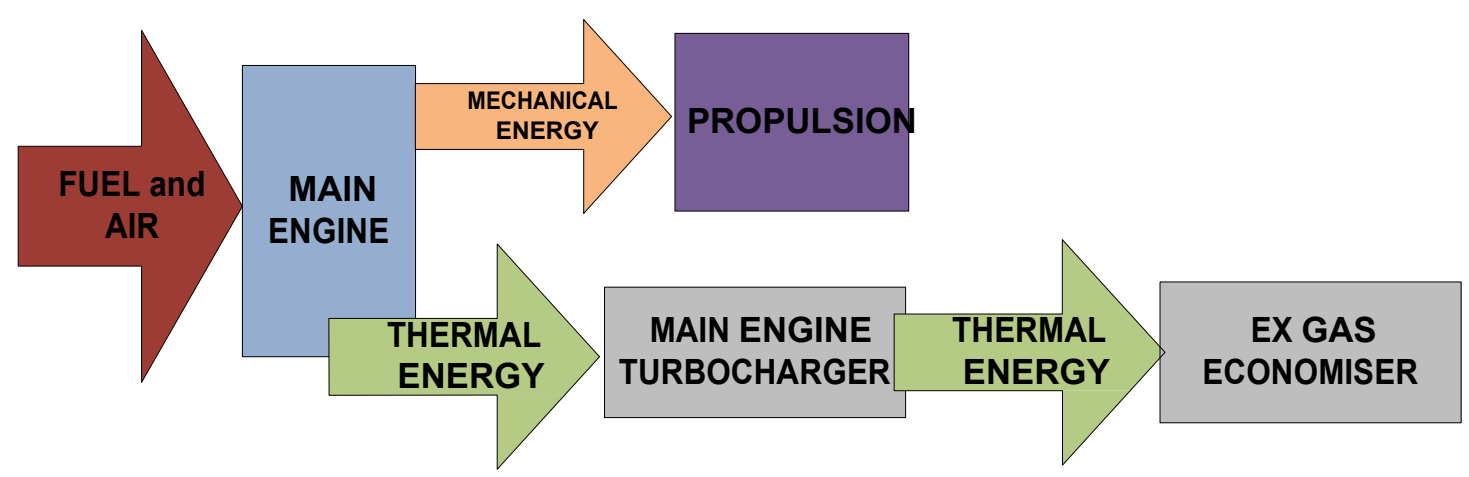

Fig. 5. Simplified Sankey diagram

\section{CONCLUS IONS}

The paper treated the energy analys is of a VLCC tanker ship, based on main engine parameters onboard ship. The energy balance analys is was used for calculating the potential for waste heat recovery on the tanker power demand among consumers.

There are numerous ways to reduce fuel consumption on board ships and to save energy resources. The use of residual heat of exhaust gas from engines to power turbochargers, as well as increased stroke, increas es the efficiency of main and auxiliary engines. Increasing engine power leads to increased mechanical work developed by the engine used to propel the ship.

The heat contained in the engine cooling water is used as a heater for seawater evaporation in the case of fresh water generators producing technical water for consumers and the closed cooling circuit with technical water.

Fuel from combustion gases is used in the heat recovery hot water systems (for heating fuel tanks and all aggregates that require heating) and water for consumers. Also, is used for hot water supply to industrial or urban consumers, heat exchangers, boilers using hot water or steam as primary heat agent.

Today, designers and producers are seeking to introduce the most efficient installations for recovering energy on board ships. The use of a turbogenerator would us e exhaust gas to produce the electric power needed to power the main engine and all other onboard marine equipments.

The exhaust gas energy from the main engine enters a turbine that operates a generator to produce useful energy (transforming heat into electricity).

\section{REFERENCES}

[1] Faităr, C., Novac, I. A new approach on the upgrade of energetic system based on green energy. A complex comparative analysis of the EEDI and EEOI, ModTech International Conference Modern Technologies in Industrial Engineering, 15-18 June, 2016, Iasi, Romania.

[2] Faităr C., Novac, I. Basic aspects and contributions to the optimization of energy systems exploitation of a super tanker ship, ModTech International Conference Modern Technologies in Industrial Engineering, 14-17 June 2017, Sibiu, Romania.

[3] Baldi F., Johnson H., Gabrielii C., Anderson K., Energy and Exergy Analy sis of Ship Energy Sy stems - The Case study of a Chemical Tanker, Department of Shipping and Marine Technology, Chalmers University of Technology Gothenburg, Sweden, pp. 81-85, 2015.

[4] *** Suppression of greenhouse gas emissions, http s://www.kline.co.jp/en/csr/environment/efforts/sup p res sion.html.

[5] *** UE Engines, https://www.mhimme.com/products/engine/.

[6] *** The industry's seaborne new provider, https://worldmaritimenews.com.

[7] Rusu E. Evaluation of the wave energy conversion efficiency in various coastal environments, 1st International e-Conference on Energies, 2013, c015, doi:10.3390/ece-1-c015, available online: http://www.sciforum.net/conference/ece-1/paper/2342

[8] Onea F., Rusu, E. Wind energy assessments along the BlackSea basin, Meteorological Applications, vol. 21, issue 2, pp. 316-329, 2014

[9] Buzbuchi N., Dragalina A1., Manea L., Moroianu C., Dinescu C. Motoare navale. Procese şi caracteristici (in R, Editura Didactică şi Pedagogică, Bucharest, 1997. 